Sains Malaysiana 50(4)(2021): 897-905

http://doi.org/10.17576/jsm-2021-5004-02

\title{
Anatomi dan Mikromorfologi Tetrastigma rafflesiae (Vitaceae)
}

(Anatomy and Micromorphology of Tetrastigma rafflesiae (Vitaceae))

\section{Syamsurina Arshad, Mohd Afiq Aizat Juhari*, Noraini TAlip, Nor AZIlah Abdul Wahab \& JumaAT}

ADAM

\section{ABSTRAK}

Kajian anatomi dan mikromorfologi telah dilakukan ke atas Tetrastigma rafflesiae (Miq.) Planchon, perumah kepada bunga pakma di Perak, Pahang dan Kelantan. Penglibatan kajian ini merangkumi anatomi keseluruhan tumbuhan ini, iaitu bahagian daun, batang, sulur paut dan akar kerana kajian anatomi masih dangkal di Malaysia amnya dan dunia khasnya. Sampel tumbuhan ini diperoleh dari Sungai Bongor, Grik, Perak, Sungai Yol, Raub, Pahang dan Lojing, Kelantan. Teknik piawai dalam anatomi tumbuhan digunakan dan ini melibatkan penggunaan mikroskop cahaya dan mikroskrop imbasan elektron (SEM). Hasil kajian anatomi menunjukkan T. rafflesiae mempunyai corak bekas vaskular dengan sistem tertutup pada petiol, tulang daun, batang dan akar; hablur didapati hadir pada petiol, tulang daun, lamina, peruratan, batang dan akar dan dinding antiklin abaksial dan adaksial adalah daripada lurus ke melengkung. Hasil mikromorfologi memperlihatkan spesies ini mempunyai stomata homostomatik dan hipostomatik daripada jenis diasitik. Lilin epikutikel berbentuk lembaran dan lapisan filem pada bahagian adaksial manakala berbentuk granul, lapisan filem dan lembaran pada bahagian abaksial. Hasil kajian ini dapat digunakan sebagai perintis kepada kajian anatomi spesies Tetrastigma yang lain.

Kata kunci: Anatomi; mikromorfologi; Tetrastigma rafflesiae

\section{ABSTRACT}

Anatomy and micromorphology study were undertaken on Tetrastigma rafflesiae (Miq.) Planchon, the host of Rafflesia flower in Peninsular Malaysia. The assessment included all the anatomy parts of this plant (leaves, stems, tendrils and roots) because the anatomy study of this plant still lacking in Malaysia and also the entire world. The plant samples were collected from Sungai Bongor, Grik, Perak, Sungai Yol, Raub, Pahang and Lojing, Kelantan. Standard techniques in plant anatomy were employed, including analyses under light microscopy and scanning electron microscopy (SEM). Anatomy results showed that T. rafflesiae has close vascular bundle system at petiole, midrib, stems and root; druses are present at petioles, midribs, laminas, veins, stem and roots; abaxial and adaxsial anticlinal walls are straight to curve. Micromorphology results showed that this species has homostomatic and hypostomatic stomata of diacytic type. Epicuticular wax is in layers and films at adaxial, and in granule, films and layers at abaxial. This study can be used as a pioneer for the anatomy investigation of other Tetrastigma species.

Keywords: Anatomy, micromorphology, Tetrastigma rafflesiae

\section{PENGENALAN}

Tetrastigma (Miq.) Planchon merupakan salah satu genus dalam famili Vitaceae yang terkenal di Asia Tenggara kerana ia merupakan satu-satunya holoparasit kepada Rafflesiaceae iaitu bunga terbesar di dunia (Febriyanti et al. 2013; Jamili 2004, 2001; Jumaat et al. 2016, 2013;
Latiff 2015, 1983; Nasihah et al. 2016; Wan Nuur Fatiha et al. 2016; Wen et al. 2013). Di Malaysia, 14 spesies Tetrastigma telah direkodkan iaitu 12 spesies di Malaysia Barat (Semenanjung Malaysia) dan dua spesies di Malaysia Timur (Sabah dan Sarawak) (Jamili 2004; Jumaat et al. 2016, 2013; Latiff \& Wong 2003; Nasihah et al. 2016; Sofiyanti et al. 2016; Wan Nuur Fatiha et al. 2016; Xi et 
al. 2013). Kajian ini memberi fokus kepada satu spesies terpenting iaitu Tetrastigma rafflesiae Planchon yang merupakan perumah kepada 11 spesies Rafflesia yang terdapat di negara ini.

Tetrastigma rafflesiae dikenali dengan pelbagai nama tempatan seperti anggur liar, akar papan, akar cabang lima, kangkong gajah (Tan 2006), akar engkarana (Wan Nuur Fatiha et al. 2016) dan lipoi (Muhammad et al. 2014). Ia merupakan sejenis tumbuhan liana berkayu daripada spesies anggur liar (Jamili 2004, 2001; Kamarudin 2007; Krishna et al. 2014; Latiff 1983; Nasihah et al. 2016; Veldkamp 2007). Menurut Tan et al. (2013) spesies ini merupakan tumbuhan berstatus amat terancam di Singapura manakala di Malaysia ia berstatus tumbuhan dilindungi (Slivinske 2008). Menurut Latiff (1983) spesies ini mempunyai taburan di India, Myanmar, Laos, Thailand, Kampuchea, Vietnam, Filipina, Malaysia, Brunei dan Indonesia dengan mendiami di pelbagai habitat seperti di hutan dipterokarpa pamah, dipterokarpa bukit dan batu kapur.

Kajian anatomi dan mikromorfologi daun T. rafflesiae di Malaysia masih dangkal dan kajian yang paling hampir ialah kajian Nasihah et al. (2016) ke atas Tetrastigma hookeri (Lowson) Planchon di Lojing Kelantan dan kajian Najmaddin et al. (2013) ke atas empat spesies Vitaceae yang terdapat di Malaysia, iaitu Tetrastigma cruciatum (Craib \& Gagnepain), Pterisanthes miquelii (Planchon),
Cissus hastata (Miquel) dan Nothocissus spicifera (Griff.) Latiff. Oleh yang demikian, kajian $T$. rafflesiae ini amat diperlukan dalam menghuraikan dengan terperinci ciri anatomi dan mikromorfologi daun pada keratan rentas petiol, tulang daun, lamina, tepi daun, batang, akar dan sulur paut, peruratan lamina dan tepi daun serta ciri mikromorfologi permukaan epidermis adaksial dan abaksial daun. Penemuan daripada kajian ini seterusnya dapat menyumbang kepada huraian lengkap ciri anatomi dan mikromorfologi daun spesies ini, dan seterusnya dapat membantu dalam kajian fisiologi dan pembiakan alternatif tumbuhan ini di Malaysia.

\section{BAHAN DAN KAEDAH}

Sampel daun T. rafflesiae telah diperoleh dari Sungai Bongor, Grik, Perak, Sungai Yol, Raub, Pahang dan Lojing, Kelantan dan seterusnya dijadikan spesimen baucar (Jadual 1). Kaedah dan teknik yang digunakan dalam penyediaan sampel daun, batang, sulur paut dan akar untuk kajian anatomi adalah mengikut Sass (1958) dan Johansen (1940) dengan pengubahsuaian meliputi teknik kikisan, kaedah rendaman dengan larutan Jeffery, cerapan di bawah mikroskop cahaya dan mikroskop imbasan elektron (SEM) serta teknik yang berkaitan dengannya. Sebanyak tiga hingga empat replikasi dilakukan bagi memastikan kemalaran ciri anatomi pada spesies kajian.

JADUAL 1. Spesimen baucar untuk kajian anatomi daun

\begin{tabular}{cccc}
\hline Spesies & Kod dan tarikh kutipan & Lokaliti & Pengumpul \\
\hline Tetrastigma rafflesiae & SBA0036/2014 & Sungai Yol, Raub, & $\begin{array}{c}\text { Syamsurina, Nor Azilah \& } \\
\text { Mohd Afiq Aizat }\end{array}$ \\
Tetrastigma rafflesiae & 16.2 .2014 & & \\
& & Pahang & Sungai Bongor, Grik, \\
Tetrastigma rafflesiae & 8.2 .2015 & Perak & Azilah \\
& & Lojing, Kelantan & Syamsurina \\
& SBA0010/2013 & & \\
\hline
\end{tabular}

\section{HASIL DAN PERBINCANGAN}

Kajian anatomi dan mikromorfologi meliputi bahagian daun, akar, batang dan sulur paut melibatkan spesimen baucer dari tiga negeri, iaitu Perak, Pahang dan Kelantan. Hasil kajian menunjukkan tidak terdapat perbezaan terhadap ciri anatomi dan mikromorfologi bagi sampel daun dari tiga lokaliti yang berbeza tersebut. Namun, kajian ini menunjukkan terdapat ciri anatomi dan mikromorfologi daun yang mungkin berguna untuk pengecaman dan pembezaan spesies. Kajian spesies Tetrastigma lain 
di Malaysia wajar dilakukan untuk melihat perbezaan ciri anatomi dan mikromorfologi antara spesies yang berlainan. Kajian ini juga merupakan kajian anatomi pertama dilakukan ke atas $T$. rafflesiae yang terdapat di Malaysia. Ini merupakan kajian perintis terhadap spesies ini kerana berdasarkan kajian kepustakaan belum ada lagi kajian bagi spesies ini. Kajian anatomi paling serupa ialah oleh Nasihah et al. (2016) ke atas T. hookeri di Kelantan dan Najmaddin et al. (2013) ke atas T. cruciatum di Malaysia.

Hasil kajian menunjukkan kehadiran lapisan sel kolenkima dan sel sklerenkima pada petiol T. rafflesiae (Rajah 1(A)). Sel kolenkima dan sel sklerenkima merupakan tisu sokongan kepada bahagian petiol (Fahn 1967). Berkas vaskular merupakan saluran pengangkut yang mengawal tisu-tisu yang terdiri daripada xilem dan floem. Tetrastigma rafflesiae mempunyai berkas vaskular jenis tertutup dan terdiri daripada satu gegelang. Tisu vaskular ini terdiri daripada beberapa berkas vaskular (19-20 berkas vaskular) pada bahagian petiol (Rajah 1(A)) dan (38-40 berkas vaskular) pada bahagian batang yang tersusun secara tidak selanjar bentuk hampir oblong (Rajah 2(A) \& 2(B)). Hasil kajian menunjukkan kuantiti berkas vaskular pada bahagian batang adalah dua kali ganda berbanding yang terdapat pada petiol. Menurut Fahn (1967) lagi, bahagian berkas vaskular pada sesuatu spesies juga boleh digunakan untuk mengenal pasti habit sesuatu spesies tumbuhan dan bilangan berkas vaskular yang banyak menggambarkan ciri liana pada T. rafflesiae.

Tulang daun merupakan bahagian tumbuhan khusus yang terdiri daripada kumpulan tisu khas (floem dan xilem) dan tisu lain yang kebiasaanya adalah sama antara individu dalam spesies yang sama. Bahagian ini kurang mengandungi sel mesofil berbanding bahagian daun yang lain (da Silva et al. 2015). Bagi T. rafflesiae, 3/4 daripada tulang daun sangat ketara dipenuhi oleh sel sklerenkima yang terletak di bawah bahagian abaksial dan di luar kawasan berkas vaskular (Rajah 1(B)). Ciri anatomi ini menggambarkan bahawa sel sklerenkima merupakan sel yang membantu memberi sokongan kepada liana.

Lamina merujuk kepada helaian daun atau bahagian daun yang berkembang (Cutler 1978). Kekuatan, keliatan dan ketegaran lamina akan meningkat dengan keamatan cahaya yang turut meningkat. Keadaan ini berlaku disebabkan oleh sel palisad yang akan berubah ketebalan menjadi sel yang lebih tebal bagi mengelakkan transpirasi berlebihan pada tumbuhan tersebut (Onoda et al. 2008). Pada T. rafflesiae, hablur drus hadir dalam dua hingga tiga lapisan pada bahagian adaksial dan satu lapisan pada bahagian abaksial. Selain itu, mesofil span turut hadir pada bahagian lamina ini (Rajah 1(C) \& 1(D)).
Kehadiran kedua-dua sel ini dilihat membantu dalam memberikan perlindungan dan mengurangkan kecederaan kepada $T$. rafflesiae sewaktu memanjat tumbuhan lain serta daripada serangan haiwan dan serangga yang terdapat di dalam hutan. Pemerhatian di lapangan menunjukkan ciri anatomi yang terdapat pada bahagian lamina ini membantu tumbuhan ini untuk tumbuh dengan subur di dalam hutan walaupun dengan vegetasi yang padat.

Seterusnya, pada bahagian akar T. rafflesiae terdapat lima hingga tujuh lapisan epidermis (Rajah 2(C) \& 2(D)). Ini menunjukkan lapisan tersebut adalah tebal bagi melindungi sel akar seterusnya membolehkan akar bergerak jauh ke dalam tanah yang amat padat. Menurut Lux dan Rost (2012), akar menjelajah ke seluruh bahagian tanah dengan meningkatkan luas permukaannya dengan unjuran rerambut akar, rizosfera, bersimbiotik dengan bakteria dan fungi tanah. Kajian mengenai akar tumbuhan juga bukanlah bidang baru dalam biologi kerana kajian mengenainya telah dilakukan semenjak 100 tahun yang lepas. Perkembangan akar meliputi tiga fasa utama iaitu, spesifikasi pertumbuhan sel akar rerambut mengikut bahagian, pertumbuhan akar rerambut dan pembahagian akar rerambut melalui hujung akar (Huang et al. 2017).

Sulur paut merupakan bahagian tumbuhan yang banyak mengalami transformasi dan pengubahsuaian sel daripada aspek mekanikal dan fungsi (Gerbode et al. 2012). T. rafflesiae didapati mempunyai empulur hampir $80 \%$ pada sulur pautnya (Rajah 2(E) \& 2(F)). Empulur ini memberikan kekuatan $T$. rafflesiae untuk memanjat tumbuhan lain dengan membina sokongan mekanikal yang stabil seterunya untuk membantu bagi menembusi cahaya matahari di dalam hutan. Narasimhan (2015) menyatakan bahawa bahagian posterior sulur paut sangat kuat manakala bahagian terminal yang berbentuk spring bertindak sebagai penahan ketegangan bagi mengimbangi berat daunnya. Jadual 2 menunjukkan ringkasan ciri anatomi T. rafflesiae.

Kajian mikromorfologi pula memperlihatkan kehadiran lilin pada $T$. rafflesiae dalam kepelbagaian bentuk pada permukaan abaksial dan adaksial. Kehadiran lilin epikutikel ini juga didapati sangat padat. Menurut Konlechner dan Sauer (2016), terdapat 23 jenis lilin epikutikular yang melekat dan tersusun dalam keadaan yang bersistematik pada daun tumbuhan yang dapat digunakan untuk pengkelasan taksonomi peringkat tinggi. Jenis lilin ini pula dapat dikelaskan kepada bentuk filem, lapisan dan berkerak (lapisan licin, berkerak atau lapisan merekah), hablur (kristaloid), granul, platelet, plat (keseluruhan berplatelet, platelet tidak sekata atau platelet bermembran), rodlet (rodlet berpoligon, rodlet terete, rotlet berlingkar atau rodlet rabung melintang), bebenang, tiub (nonacosanol atau dwiketon) dan bentuk kristal beralih 
(Barthlott et al. 1998). Lilin pada T. rafflesiae berbentuk lembaran dan lapisan filem pada epidermis adaksial (Rajah 3) manakala berbentuk granul, lapisan filem dan lembaran pada epidermis abaksial daun (Rajah 4). Menurut Martin dan Juniper (1970), lapisan ini merupakan lapisan yang lut pada cahaya, rintang air, membenarkan pertukaran gas melalui kutikel kepada stomata, melindungi daun daripada kecederaan akibat angin yang kuat atau timpaan air hujan berlebihan, melindungi daripada serangan patogen dan serangga.

Perbandingan anatomi antara T. hookeri (Nasihah et al. 2016), T. cruciatum (Najmaddin et al. 2013) dan T. rafflesiae menunjukkan perbezaan yang jelas bagi ketiga-tiga spesies ini (Jadual 3). Pada keratan rentas petiol, ketiga-tiga spesies Tetrastigma ini mempunyai persamaan dengan permukaan abaksial berbentuk bulatan dan adaksial berbentuk cembung dan bercuping. Pada sel epidermis pula, T. cruciatum dan T. hookeri mempunyai satu lapisan dengan nisbah tinggi kepada lebar 2:1. Sementara itu, lapisan sel epidermis pada $T$. rafflesiae dengan nisbah tinggi kepada lebar adalah 1:2. Pada keratan rentas tulang daun pula, permukaan adaksial bagi T. rafflesiae dan T. hookeri berbonggol manakala $T$. cruciatum berbentuk cembung. Pada permukaan abaksial, T. rafflesiae bebentuk-U, T. cruciatum berbentuk arka dan T. hookeri berbentuk bulatan tidak sama rata. Ketiga-tiga spesies Tetrastigma ini mempunyai persamaan lain, iaitu hablur drus dan granul kanji hadir pada majoriti bahagian anatomi yang dikaji.

JADUAL 2. Ringkasan ciri anatomi T. rafflesiae

\begin{tabular}{|c|c|}
\hline Ciri & Huraian \\
\hline Corak berkas vaskular petiol & $\begin{array}{l}\text { Sistem tertutup } \\
\text { Satu gegelang, tisu vaskular yang terdiri daripada beberapa berkas vaskular (19-20 } \\
\text { berkas vaskular) tersusun secara tidak selanjar bentuk hampir bentuk-O berlekuk } \\
\text { pada bahagian adaksial }\end{array}$ \\
\hline Corak berkas vaskular tulang anak daun & $\begin{array}{l}\text { Sistem tertutup } \\
\text { Satu gegelang tisu vaskular yang terdiri daripada beberapa berkas vaskular (7-9 } \\
\text { berkas vaskular) tersusun secara tidak selanjar bentuk-O }\end{array}$ \\
\hline Corak berkas vaskular batang & $\begin{array}{c}\text { Sistem tertutup } \\
\text { Satu gegelang, tisu vaskular yang terdiri daripada beberapa berkas vaskular (38-40 } \\
\text { berkas vaskular) tersusun secara selanjar bentuk hampir oblong }\end{array}$ \\
\hline Corak berkas vaskular akar & $\begin{array}{l}\text { Sistem tertutup } \\
\text { Terdiri daripada tisu vaskular poliarka yang merupakan oktarka (8 cabang) }\end{array}$ \\
\hline Kehadiran hablur & Hadir pada petiol, tulang daun, lamina, peruratan, batang dan akar \\
\hline Bentuk luaran petiol & $\begin{array}{c}\text { Adaksial: cembung dan terdapat struktur seperti cuping membulat pada kawasan } \\
\text { pertemuan bahagian adaksial dan abaksial } \\
\text { Abaksial: berbentuk } 3 / 4 \text { bulatan }\end{array}$ \\
\hline Bentuk luaran tulang anak daun & $\begin{array}{l}\text { Adaksial: berbonggol } \\
\text { Abaksial: berbentuk-U dengan dasar rata }\end{array}$ \\
\hline Bentuk luaran batang & $\begin{array}{l}\text { Adaksial: cembung dan membentuk dataran hampir rata } \\
\text { Abaksial: berbentuk } 3 / 4 \text { oblong }\end{array}$ \\
\hline Bentuk luaran akar & Bulat \\
\hline Bentuk luaran sulur paut & Bulat \\
\hline Bentuk tepi anak daun & $\begin{array}{c}\text { Membulat } \\
\text { Melengkung } 30^{\circ}-45^{\circ} \text { menghala ke arah epidermis abaksial, saiz sedikit mengecil } \\
\text { menuju hujung tepi daun }\end{array}$ \\
\hline Dinding antiklin abaksial & Lurus ke melengkung \\
\hline Dinding antiklin adaksial & Lurus ke melengkung \\
\hline Jenis stomata & $\begin{array}{l}\text { Homostomatik dan hipostomatik (hadir hanya pada permukaan abaksial) } \\
\text { Jenis diasitik }\end{array}$ \\
\hline Lilin epikutikel & $\begin{array}{l}\text { Adaksial: Berbentuk lembaran dan lapisan filem } \\
\text { Abaksial: Berbentuk granul, lapisan filem dan lembaran }\end{array}$ \\
\hline
\end{tabular}


JADUAL 3. Perbandingan ciri anatomi pada petiol dan tulang daun

\begin{tabular}{|c|c|c|}
\hline Spesies & Petiol & Tulang daun \\
\hline T. rafflesiae & & \\
\hline $\begin{array}{c}\text { T. hookeri } \\
\text { (Nasihah et al. 2016) }\end{array}$ & & \\
\hline $\begin{array}{c}\text { T. cruciatum } \\
\text { (Najmaddin et al. 2013) }\end{array}$ & & \\
\hline
\end{tabular}
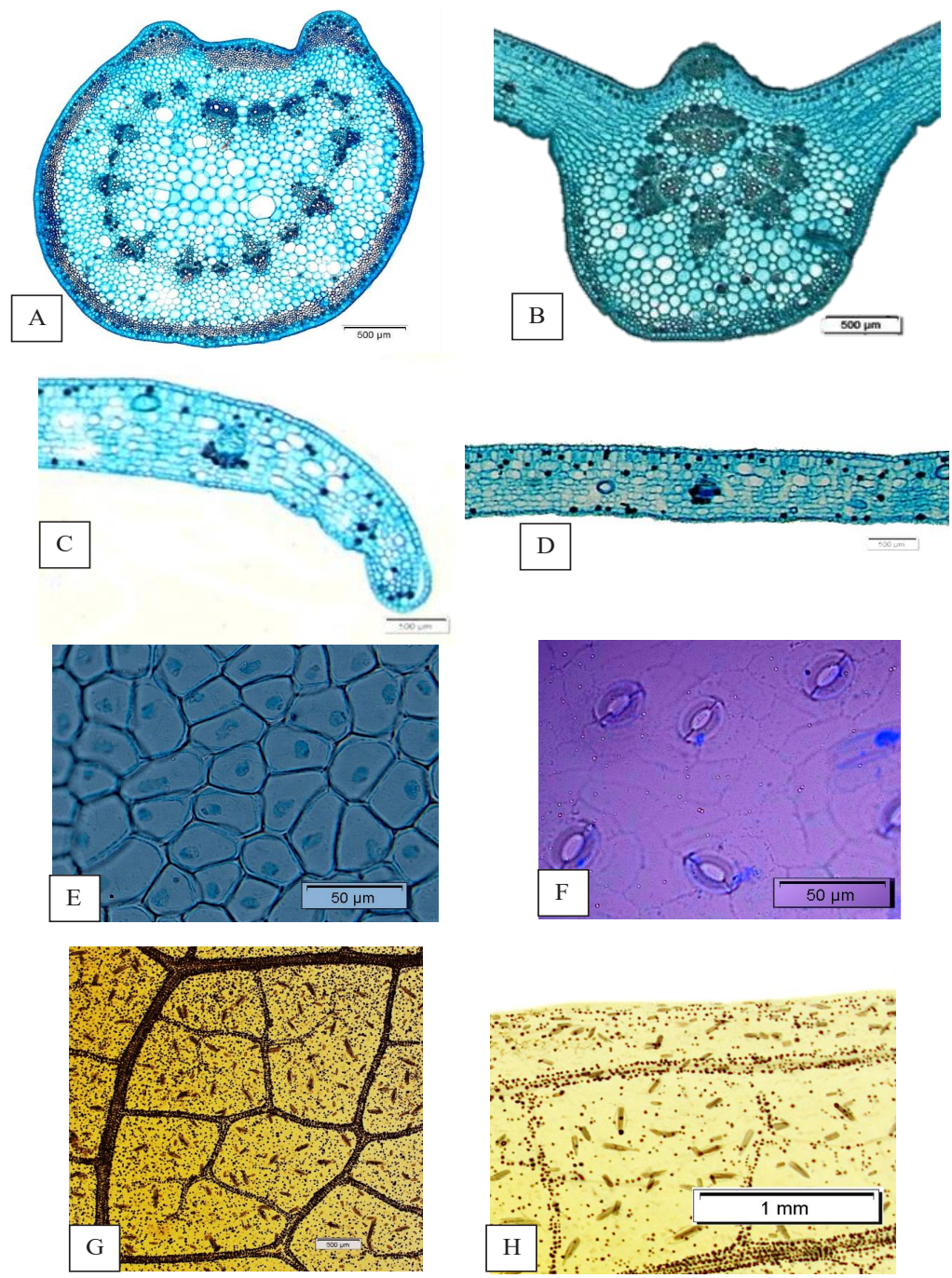

RAJAH 1. Anatomi daun T. rafflesiae. A: KR petiol, B: KR tulang daun, C: KR tepi anak daun, D: KR lamina anak daun, E: dinding antiklin epidermis adaksial, $\mathrm{F}$ : dinding antiklin epidermis abaksial, $\mathrm{G}$ : peruratan tengah, dan $\mathrm{H}$ : peruratan tepi. Skala: A, B, C, D \& G $=500 \mu \mathrm{m}, \mathrm{E} \& \mathrm{~F}=50 \mu \mathrm{m}$, dan $\mathrm{H}=1 \mathrm{~mm}$ 

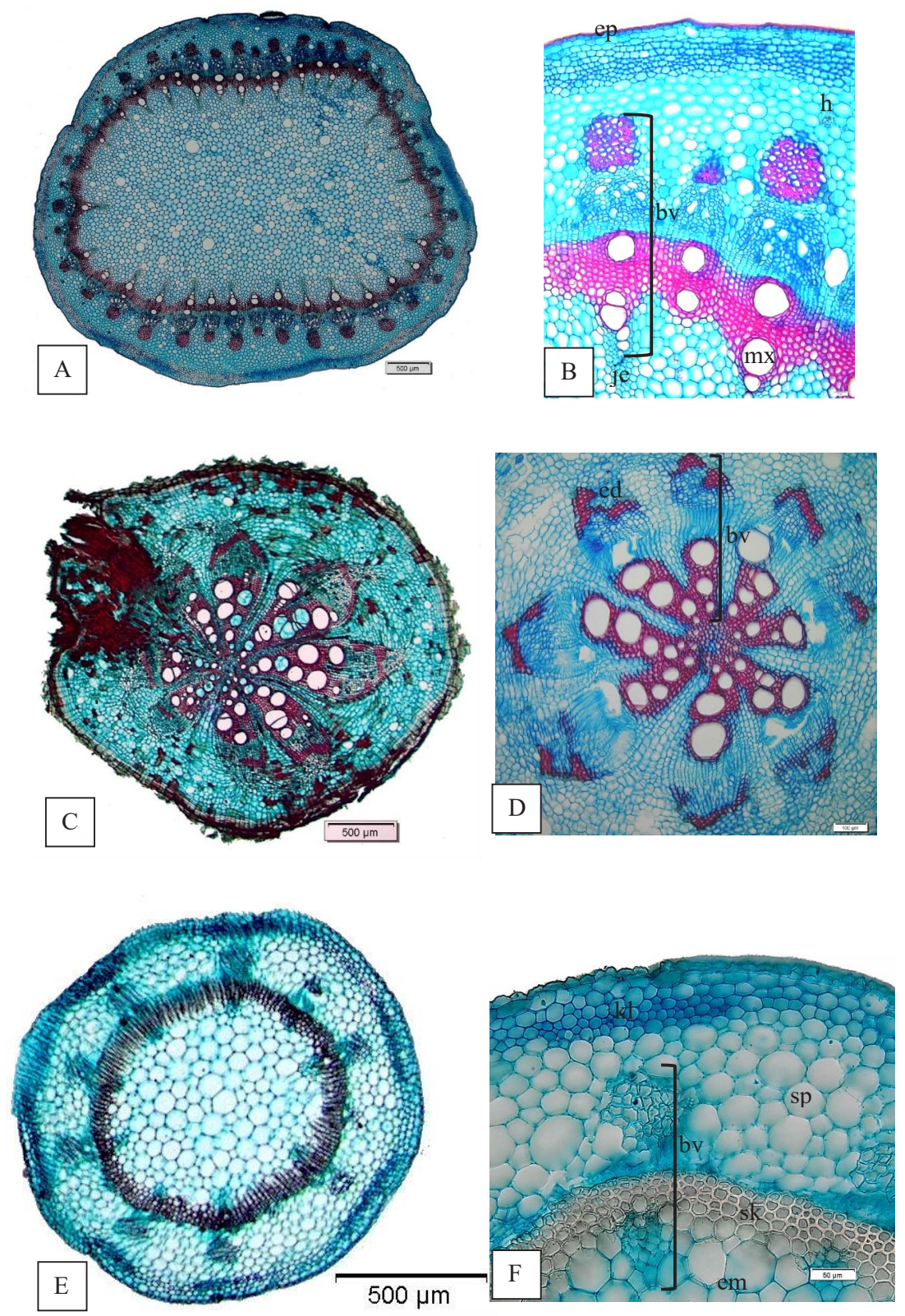

RAJAH 2. Anatomi batang, akar dan salur paut T. rafflesiae. A: KR batang, C: KR akar, dan E: KR sulur paut. ep: lapisan epidermis, bv: berkas vaskular, je: jaluran empulur, h: hablur drus, mx: metaxilem, ed: endodermis, kl: sel kolenkima, sp: sel parenkima, sk: sel sklerenkima, dan em: empulur. Skala: A, B, C, D \& G $=500 \mu \mathrm{m}, \mathrm{E} \& \mathrm{~F}=50 \mu \mathrm{m}$, dan $\mathrm{H}=1 \mathrm{~mm}$ 

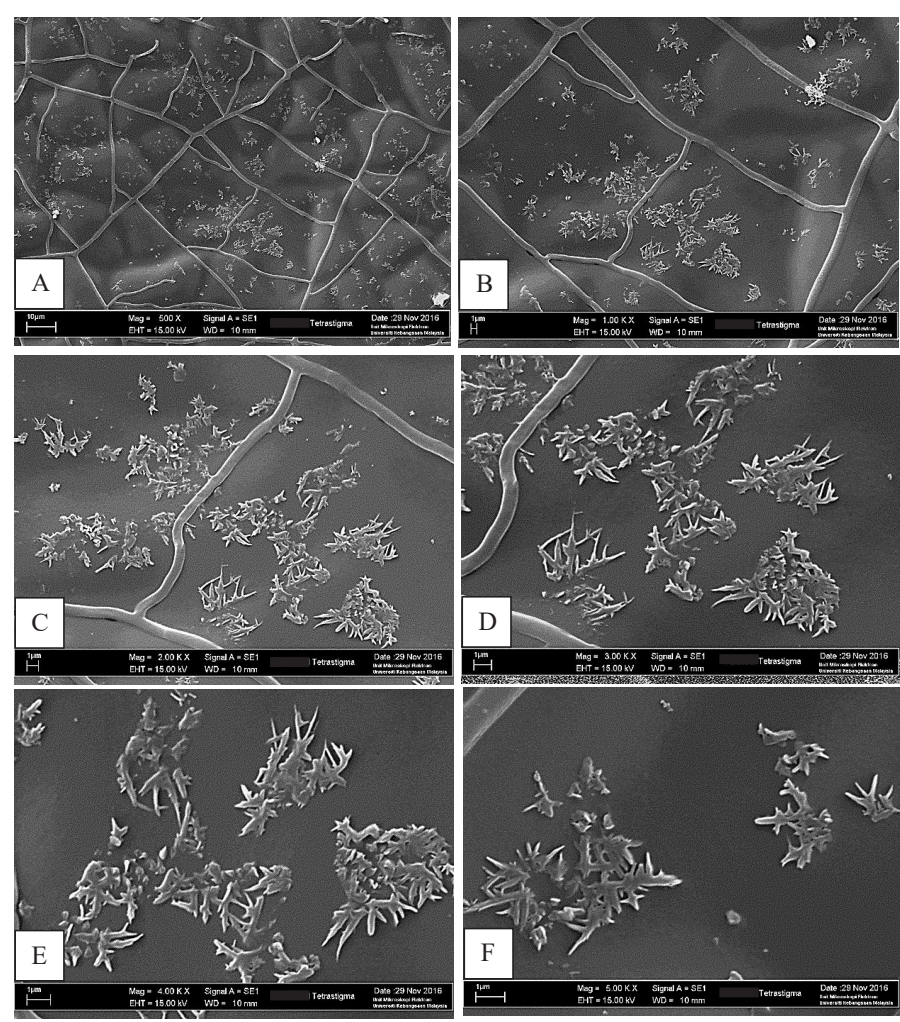

RAJAH 3. Permukaan epidermis adaksial daun T. rafflesiae. A \& B: hiasan kutikel jelas, dinding antikilin tenggelam, dan dinding perikilin timbul, dan C-F: lilin lembaran dan lapisan filem. Skala: A $=10 \mu \mathrm{m}$, dan B-F $=1 \mu \mathrm{m}$
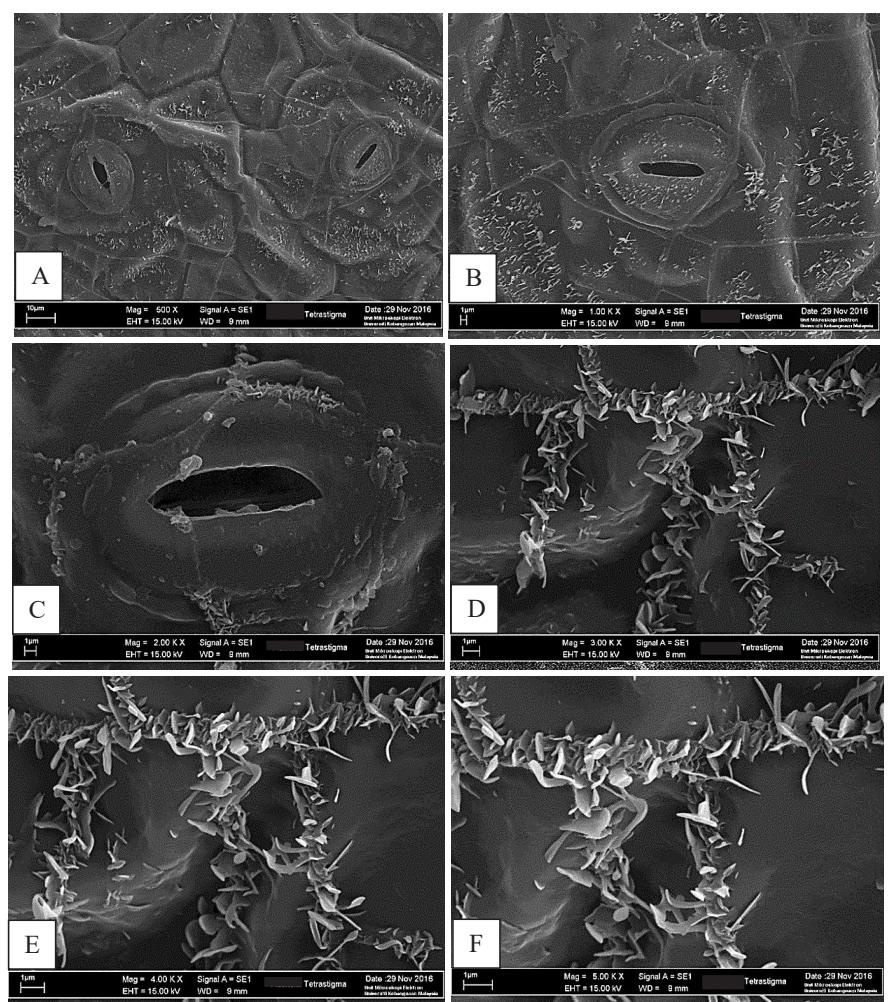

RAJAH 4. Permukaan epidermis abaksial daun T. rafflesiae. A \& B: taburan stomata (hiasan kutikel jelas, dinding antikilin tenggelam, dinding perikilin timbul), C: stomata (hipostomatik, superfisial, bentuk elips, bingkai stomata jelas, birai stomata jelas dan timbul, sel epidermis/sel subsidiari merangkumi stomata), dan D-F: lilin (lapisan filem, granul dan lembaran). Skala: $\mathrm{A}=10 \mu \mathrm{m}$, dan $\mathrm{B}-\mathrm{F}=1 \mu \mathrm{m}$ 


\section{KESIMPULAN}

Kajian ini telah menghuraikan secara khusus ciri anatomi dan mikromorfologi daun, batang, sulur paut dan akar T. rafflesiae bagi membolehkan dapatan maklumat secara komprehensif untuk tujuan pengecaman. Hasil kajian ini juga berguna untuk kajian lanjut yang memerlukan ciri anatomi sebagai maklumat asas. Hasil kajian turut menunjukkan ciri anatomi daun, batang dan akar T. rafflesiae dari ketiga-tiga negeri/lokasi tidak mempengaruhi struktur vegetatif spesies ini. Selain itu, kajian ini menunjukkan $T$. rafflesiae mempunyai ciri anatomi yang jelas, dan ia dapat dibezakan dengan spesies Tetrastigma lain. Hasil mikromorfologi pula merupakan maklumat terbaharu yang berguna sebagai data tambahan untuk spesies ini. Kajian ini telah berjaya mengupas beberapa perkara mengenai spesies unik ini yang amnya kurang dikenali berbanding parasitnya. Walau bagaimanapun, masih banyak maklumat diperlukan dan kajian yang perlu dijalankan untuk spesies ini pada masa hadapan.

\section{PENGHARGAAN}

Penulis mengucapkan setinggi-tinggi penghargaan kepada kakitangan di Makmal Mikroteknik, UKM dan Makmal Histologi, Institut Agro-Bioteknologi Malaysia, MARDI. Penghargaan kepada geran penyelidikan FRGS/1/2014/ST03/UKM/01/1 kerana membiayai kajian ini.

\section{RUJUKAN}

Barthlott, W., Neinhuis, C., Cutler, D., Ditsch, F., Meusel, I., Theisen, I. \& Wilhelmi, H. 1998. Classification and terminology of plant epicuticular waxes. Botanical Journal of the Linnean Society 126(3): 237-260.

Cutler, D.F. 1978. Applied Plant Anatomy. New York: Longman Group Limited.

da Silva, N.R., Florindo, J.B., Gómez, M.C., Rossatto, D.R., Kolb, R.M. \& Bruno, O.M. 2015. Plant identification based on leaf midrib cross-section images using fractal descriptors. PLOS ONE 10(6): 1-14.

Fahn, A. 1967. Plant Anatomy. London: Pergamon Press Ltd.

Febriyanti, E., Suwirmen \& Idris, M. 2013. Induksi perakaran tunas Tetrastigma rafflesiae Miq. pada media Murashigeskoog dengan penambahan beberapa konsentrasi indole-3butyric acid (IBA) secara in vitro. Jurnal Biologi Universitas Andalas 2(2): 161-167.

Gerbode, S.J., Puzey, J.R., McCormick, A.G. \& Mahadevan, L. 2012. How the cucumber tendril coils and overwinds? Science 337(6098): 1087-1091.

Huang, L., Shi, X., Wang, W., Ryu, K.H. \& Schiefelbein, J. 2017. Diversification of root hair development genes in vaskular plants. Plant Physiology 174(3): 1697-1712.
Jamili, N. 2004. Rafflesia Bunga Terbesar di Dunia. Kota Kinabalu: Natural History Publication.

Jamili, N. 2001. Rafflesia of the World. Kota Kinabalu: Penerbit Sabah Parks.

Johansen, D.A. 1940. Plant Microtechnique. New York: McGrawHill Book Company Inc.

Jumaat, H.A., Mohd Afiq Aizat, J., Rahmah, M., Nor Azilah, A.W., Syamsurina A., Mohd Paiz, K., Mohd Firdaus, M.R. \& Kiew-Lian, W. 2016. Rafflesia tuanku-halimii (Rafflesiaceae): A new species from Peninsular Malaysia. Sains Malaysiana 45(11): 1589-1595.

Jumaat, H.A., Rahmah, M., Mohd Afiq Aizat, J., Nik Nadira Farhana, N.A. \& Kiew-Lian, W. 2013. Rafflesia sharifahhapsahiae (Rafflesiaceae), a new species from Peninsular Malaysia. Turkish Journal of Botany 37(6): 1038-1044.

Kamarudin, M.S. 2007. Rafflesia: Magnificient Flower of Sabah. Kota Kinabalu: Natural History Publications (Borneo).

Konlechner, C. \& Sauer, U. 2016. Ultrastructural leaf features of grapevine cultivars. (Vitis vinifera L. ssp. vinifera). OENO One 50(4): 195-207.

Krishna, T.P.A., Krishna, T.P.A., Chithra, N.D., Deepa, P.E., Darsana, U., Sreelekha, K.P., Juliet, S., Nair, S.N., Ravindran, R., Kumar, K.G.A. \& Ghosh, S. 2014. Acaricidal activity of petroleum ether extract of leaves of Tetrastigma leucostaphylum (Dennst.) Alston against Rhipicephalus (Boophilus) annulatus. The Scientific World Journal 2014: $1-6$.

Latiff, A. 2015. Studies in Malesian Vitaceae XV. Revision of Tetrastigma (Miq.) Planch. Sect. Carinata Latiff. Malayan Nature Journal 67(3): 318-327.

Latiff, A. 1983. Studies in Malesian Vitaceae VII. The genus Tetrastigma in the Malay Peninsula. Gardens Bulletin of Singapore 36(2): 213-228.

Latiff, A. \& Wong, M. 2003. A new species of Rafflesia from Peninsular Malaysia. Folia Malaysiana 4: 135-146.

Lux, A. \& Rost, T.L. 2012. Plant root research: The past, the present and the future. Annals of Botany 110(2): 201-204.

Martin, J.T. \& Juniper, B.E. 1970. The Cuticles of Plants. Edinburgh: Edward Arnold (Publishers) Ltd.

Muhammad, A.Z., Nor, S.O., Zaini, Y., Mohd Lias, K. \& Jamil, T. 2014. Identification of alkaloid compound and antioxidant activity of Rafflesia cantleyi and its host, Tetrastigma tuberculatum. The Open Conference Proceedings Journal 5: 18-20.

Najmaddin, C., Hussin, K. \& Maideen, H. 2013. Comparative leaf anatomy of selected species in Vitaceae and Leeaceae. American Journal of Applied Sciences 10(4): 414-417.

Narasimhan, S. 2015. Morphometric characters determine tendril biomechanics of Luffa acutangula var. acutangula. In 4th World Conference on Applied Sciences, Engineering \& Technology. Anjuran Kumamoto University, Jepun.

Nasihah, M., Zulhazman, H., Siti Munirah, M.Y., Wan Norqayyum Nadia, W.A. \& Latiff, A. 2016. Tetrastigma hookeri (Laws.) Planch. (Vitaceae), a host plant for Rafflesia kerrii Meijer in Peninsular Malaysia. Malayan Nature Journal 68(1\&2): 33-39. 
Onoda, Y., Schieving, F. \& Anten, N.P.R. 2008. Effects of light and nutrient availability on leaf mechanical properties of plantago major: A conceptual approach. Annals of Botany 101: 727-736.

Sass, J.E. 1958. Botanical Microtechnique. Edisi ke-3. Ames: Iowa State University Press.

Slivinske, S. 2008. Rafflesia breeding conservation. Hort 404-Plant Breeding.

Sofiyanti, N., Kamarudin, M.S., Khairil, M., Nor Zuhailah, M., Mohd Ros, A.H. \& Burslem, D.F.R.P. 2016. Rafflesia parvimaculata (Rafflesiaceae), a new species of Rafflesia from Peninsular Malaysia. Phytotaxa 253(3): 207-213.

Tan, A.L. 2006. Kajian Rafflesia Kuala Melantai Pahang. Tesis Sarjana Muda, Universiti Kebangsaan Malaysia (Tidak diterbitkan)

Tan, S.Y., Koh, C.Y., Siow, H.J.M., Li, T., Wong, H.F., Heyzer, A. \& Tan, H.T.W. 2013. 100 Common Vascular Plants of the Nee Soon Swamp Forest, Singapore. Singapore: Raffles Museum of Biodiversity Research.

Veldkamp, J.F. 2007. The correct name for the Tetrastigma (Vitaceae) host of Rafflesia (Rafflesiaceae) in Malesia and a (not so) new species. Reinwardtia 12(4): 261-265.
Wan Nuur Fatiha, W.Z., Aida Shafreena, A.P., Geri, C., Ramlah, Z. \& Latiff, A. 2016. Tetrastigma diepenhorstii (Miq.) Latiff (Vitaceae), a new host of Rafflesia Tuan-mudae Becc. (Rafflesiaceae) in Borneo. Journal of Botany 2016: 1-6.

Wen, J., Lu, L. \& Boggan, J.K. 2013. Diversity and evolution of Vitaceae in the Philippines. Philippine Journal of Science Special Issue 142: 223-244.

Xi, Z., Wang, Y., Bradley, R.K., Sugumaran, M., Marx, C.J., Rest, J.S. \& Davis, C.C. 2013. Massive mitochondrial gene transfer in a parasitic flowering plant clade. PLoS Genetics 9(2): 1-10.

Fakulti Sains dan Teknologi

Universiti Kebangsaan Malaysia

43650 UKM Bangi, Selangor Darul Ehsan

Malaysia

*Pengarang untuk surat-menyurat; email: afiqaizat@ukm.edu.my

Diserahkan: 18 September 2018

Diterima: 2 September 2020 